\title{
Reduction of Perturbations in Leucine Incorporation in Synchronous Cultures of Schizosaccharomyces pombe Made by Elutriation
}

\author{
By J. CREANOR AND J. M. MITCHISON \\ Department of Zoology, University of Edinburgh, West Mains Road, \\ Edinburgh EH9 3JT, Scotland
}

(Received 27 December 1978)

Good synchronous cultures of the fission yeast Schizosaccharomyces pombe can be made by selecting small cells from the Beckman JE-6 elutriator rotor. More important, the rate of leucine incorporation in controls shows far less perturbation than after selection from tube gradients. Elutriation may therefore be the best available method for reducing perturbations in selection synchronized cultures.

Synchronous cultures of yeasts (and other cells) have been produced for more than a decade by selecting fractions from an exponential phase culture after centrifuging in a gradient in tubes or in zonal rotors (Mitchison \& Carter, 1975). Although this method is satisfactory in the fission yeast Schizosaccharomyces pombe for measuring some cellular components, e.g. DNA, we have found recently that it causes serious perturbations in other components. These perturbations appear in synchronous cultures and also in control cultures (Mitchison \& Carter, 1975) which are put through most of the synchronizing procedure but which are not finally selected for size and are therefore asynchronous with respect to the cell cycle. Two examples are shown in Fig. 1 $(a)$ and $(b)$ for the rate of leucine incorporation, which ought to increase exponentially in an unperturbed culture. As often happened, the perturbations were different in the two cultures. Other examples occurred in assays of enzyme activity (Mitchison, 1977). Some enzymes (e.g. homoserine dehydrogenase, alcohol dehydrogenase, maltase) showed prolonged perturbations which could persist with a frequency near to the cycle time, though others did not (e.g. sucrase, phosphatase) (Mitchison \& Creanor, 1969). The perturbations might be caused by the concentration of cells during harvesting, the effects of the gradient material (e.g. sucrose or lactose) or temperature shocks during handling. We have some evidence to suggest that the concentration is the most important factor.

In an effort to find a way of producing unperturbed synchronous cultures, we tried the continuous flow selection method (Lloyd et al., 1975) but did not find it satisfactory in our hands. We have had success, however, with the Beckman JE-6 elutriator rotor and we describe the technique below. In essence, the rotor works by a counter-current method and the yeast in the $4 \mathrm{ml}$ rotor cell is kept suspended by an inward flow of medium which can

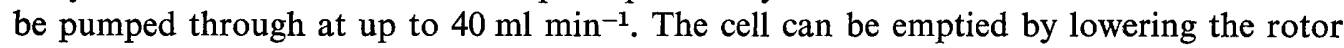
speed or raising the pump speed. The process can be watched with a stroboscope since the cell is transparent. Our method is somewhat different from those previously described for yeast (Gordon \& Elliott, 1977) and mammalian cells (Meistrich et al., 1977; Mitchell \& Tupper, 1977) since the rotor is kept at the growth temperature and the cells continue to grow while in the rotor and are not subject to a temperature shock.

The apparatus consists of a Beckman JE-6 rotor (with associated manufacturers' equipment), a Beckman J-21 centrifuge (slightly modified for this rotor by the manufacturers) and a Cole-Parmer Masterflex peristaltic pump (Fig. 2). A simple bubble trap is needed on 


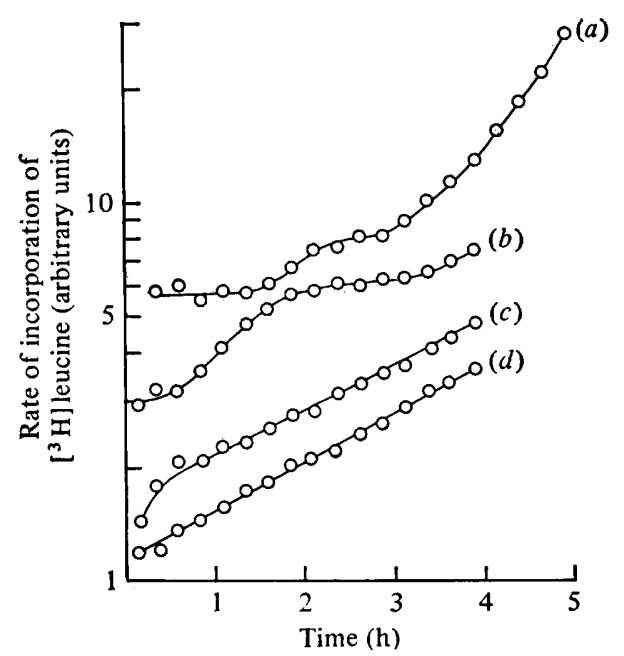

Fig. 1. Incorporation of leucine pulses in control asynchronous cultures of $S$. pombe (strain NCYC 132, ATCC 24751) grown at $32^{\circ} \mathrm{C}$ in EMM2 (Mitchison, 1970). (a) and (b), Controls for tube gradients. Growing cells were concentrated by filtration, suspended for $4 \mathrm{~min}$ in medium plus $20 \%(\mathrm{w} / \mathrm{v})$ sucrose and then diluted in the original medium to a.cell density of $2 \times 10^{6} \mathrm{cells} \mathrm{ml}^{-1}$ at time zero. Successive samples were labelled for $14 \mathrm{~min}$ with $\left[{ }^{3} \mathrm{H}\right] l$ leucine $\left(4\right.$ to $8 \mu \mathrm{Ci} \mathrm{ml}^{-1}, 50$ to $58 \mathrm{Ci} \mathrm{m}^{-1}$ ) and then treated with $5 \%$ trichloroacetic acid, filtered, washed and counted. $(c)$ and $(d)$, Controls for the elutriator rotor. Growing cells were collected in the rotor [in $(d) 6.5 \times 10^{9}$ cells were collected over a $40 \mathrm{~min}$ period]. After collection, they were pumped out and diluted in the original medium to a cell density of $2 \times 10^{6}$ cells $\mathrm{ml}^{-1}$. Labelling was as above.

the inflow line, and we have found it better to have the pump working on the outflow line rather than the inflow since it causes less turbulence in the cell. The rotor cell is loaded from an exponential phase culture of $S$. pombe at $32{ }^{\circ} \mathrm{C}$ with a pumping speed of $22 \mathrm{ml} \mathrm{min}^{-1}$. The rotor is run at about $3700 \mathrm{rev}$. $\mathrm{min}^{-1}$ without refrigeration, and care has to be taken that the yeast layer never rises above the widest part of the rotor cell in order to avoid losing the smallest yeast cells into the effluent. Loading takes 10 to $40 \mathrm{~min}$, depending on the cell density of the culture, and the maximum loading is about $7 \times 10^{9}$ cells. Above this, the rotor cell clogs up. Some of the culture medium is filtered free of cells and kept warm for subsequent resuspension and pumping out. To make a synchronous culture, the pumping speed is increased to $33 \mathrm{ml} \mathrm{min}{ }^{-1}$ but the rotor speed is left unchanged. When the layer of yeast cells has risen above the widest part of the rotor cell, $10 \mathrm{ml}$ samples of the effluent are taken in sequence. These are examined under the microscope to check for a uniform population of small cells and the best samples are pooled and diluted if necessary with filtered medium to give the synchronous culture. A good synchronous culture can contain up to $2 \times 10^{8}$ cells ( $3 \%$ of the maximum loading). To make an asynchronous control, the pumping speed is increased to $33 \mathrm{ml} \mathrm{min}{ }^{-1}$ and the rotor speed is dropped. All the yeast cells are pumped out of the rotor with filtered medium and the culture is diluted to the required cell density using the same medium.

During centrifuging, the yeast cells are maintained at $32{ }^{\circ} \mathrm{C}$ since the temperature in the rotor cell is largely determined by the temperature of the medium when the flow rate is rapid (five changes per minute) and the centrifuge is not refrigerated. There is also a continuous flow of nutrient past the yeast cells. Under these conditions, the yeast continues to grow in the rotor and we found a normal doubling in numbers when $S$. pombe (strain NCYC 132) was kept in the rotor for a generation time $(150 \mathrm{~min})$ with warm medium circulated at $33 \mathrm{ml} \mathrm{min}{ }^{-1}$.

The rotor cell needs to be cleaned after each run. It is also important to disinfect the rotor and tubing since bacteria can grow in parts of the complex circulation system. This can be 


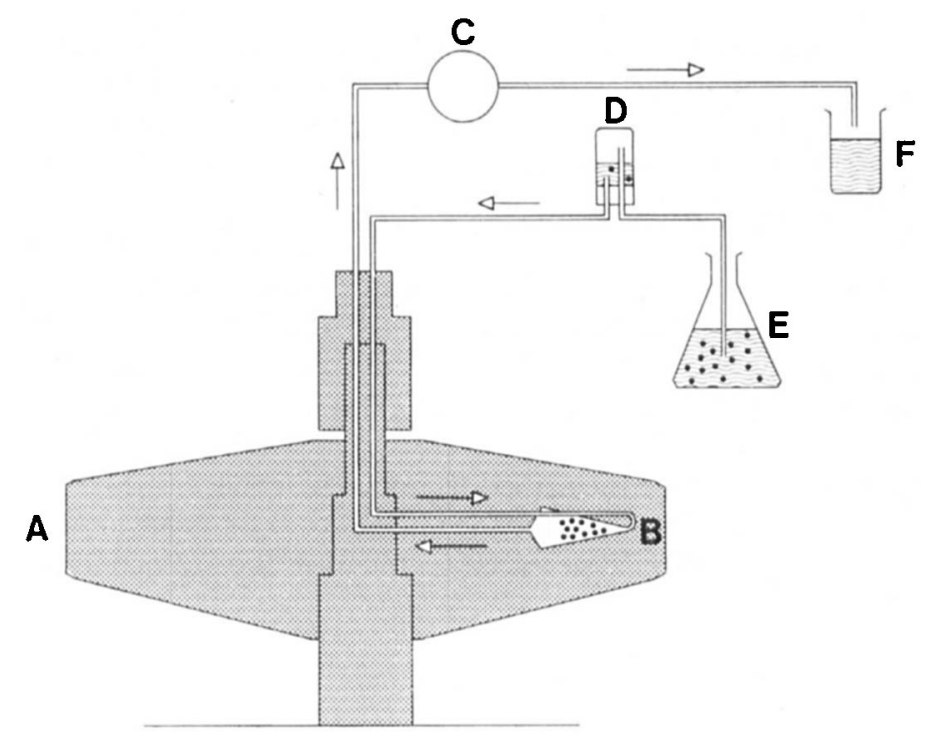

Fig. 2. Diagram of elutriator rotor: A, rotor; B, rotor cell; C, peristaltic pump; $\mathrm{D}$, bubble trap; E, culture flask; F, effluent flask.

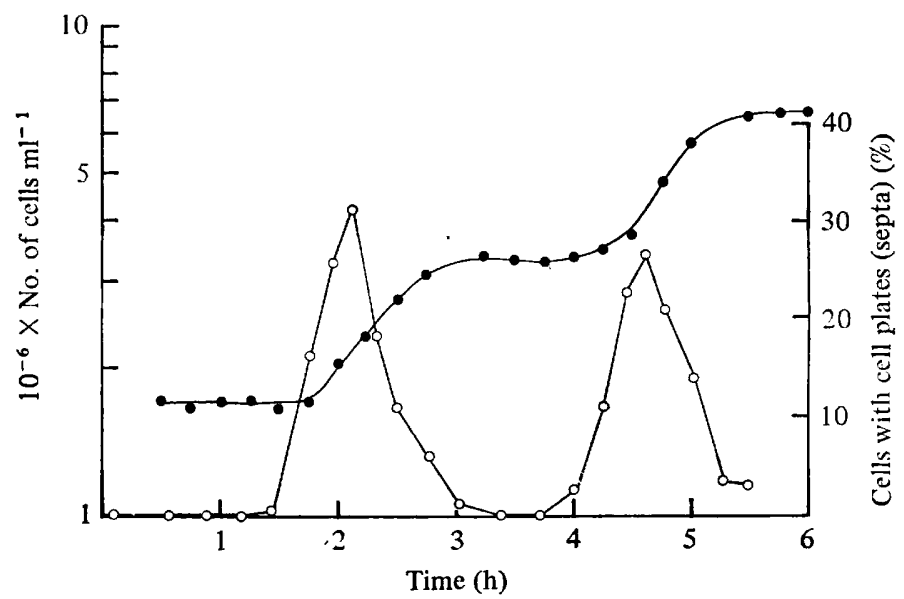

Fig. 3. Synchronous culture of $S$. pombe (strain $972 \mathrm{~h}^{-}$) at $32^{\circ} \mathrm{C}$ in modified EMM2 with phthalate buffer (Nurse, 1975). It was prepared as described in the text, and shows two synchronous divisions: -, cell number (from a Coulter counter); $O$, cell plate index (Mitchison, 1970). This figure is directly comparable with Fig. 2 in Mitchison \& Carter (1975).

done by autoclaving but we found it simpler to use a soluble disinfectant. Quaternary ammonium compounds were ineffective and glutaraldehyde left traces which affected yeast. We now use diethyl pyrocarbonate (at $0.2 \%, \mathrm{v} / \mathrm{v}$, in water) which loses its toxic effect on yeast $2 \mathrm{~h}$ after being made up. The solution is left in the rotor overnight and then washed out with 11 of sterile distilled water before the rotor is used.

Figure 3 shows an example of a synchronous culture prepared by elutriation. It is similar to those prepared by the earlier method of selection from tube gradients (Mitchison \& Carter, 1975) but the synchrony is better. Equally important are the results shown in Fig. 1(c) and $(d)$ for leucine incorporation in asynchronous control cultures. There was little or no perturbation after the first $30 \mathrm{~min}$ which was in marked contrast to the control cultures 
made by the earlier method [Fig. 1(a) and (b)]. We therefore feel more confident that effects found in synchronous cultures made by elutriation are likely to be real cell cycle effects and not spurious effects due to the method of making the cultures. Even so, control cultures are needed for each situation. When the measurements in Fig. $1(c)$ and $(d)$ were repeated with a different strain of $S$. pombe $\left(972 \mathrm{~h}^{-}\right.$) in a different minimal medium (Nurse, 1975), there were marked perturbations.

In conclusion, tube gradients are the easiest method for selection synchrony but they may not be acceptable if their controls show serious perturbations. The elutriator rotor is more likely to eliminate perturbations, but it is an expensive instrument. The yields of these two techniques are about the same, and the zonal rotor is necessary for making larger synchronous cultures. It may, however, show even greater perturbations than tube gradients.

We should like to acknowledge the skilled technical assistance of Mrs Linda Farrar. We are also grateful to Beckman RIIC Ltd for the initial loan of an elutriator rotor and centrifuge. This work was supported by a Research Grant from the Science Research Council.

\section{REFERENCES}

Gordon, C. N. \& ElliotT, S. G. (1977). Fractionation of Saccharomyces cerevisiae cell populations by centrifugal elutriation. Journal of Bacteriology 129, 97-100.

Lloyd, D., JoHn, L., Edwards, C. \& Chagla, A. H. (1975). Synchronous cultures of micro-organisms: large scale preparation by continuous-flow size selection. Journal of General Microbiology 88, 153-158.

Meistrich, M. L., Meyn, R. E. \& Barlogie, B. (1977). Synchronisation of mouse L-P59 cells by centrifugal elutriation separation. Experimental Cell Research 105, 169-177.

MrTCHELl, B. F. \& TuPPER, J. T. (1977). Synchronisation of mouse 3T3 and SV40 3T3 cells by way of centrifugal elutriation. Experimental Cell Research 106, 351-355.
Mrtchison, J. M. (1970). Physiological and cytological methods for Schizosaccharomyces pombe. Methods in Cell Physiology 4, 131-165.

Mitchison, J. M. (1977). Enzyme synthesis during the cell cycle. In Cell Differentiation in Microorganisms, Plants and Animals, pp. 377-401. Edited by L. Nover \& K. Mothes. Jena: Gustav Fischer Verlag.

Mitchison, J. M. \& Carter, B. L. A. (1975). Cell cycle analysis. Methods in Cell Biology 9, 201-219.

Mitchison, J. M. \& Creanor, J. (1969). Linear synthesis of sucrase and phosphatases during the cell cycle of Schizosaccharomyces pombe. Journal of Cell Science 5, 373-391.

NURSE, P. (1975). Genetic control of cell size at cell division in yeast. Nature, London 256, 547-551. 